\title{
Time-dependent performance of soil mix technology stabilised/ solidified contaminated site soils
}

\author{
Fei Wang ${ }^{a}{ }^{*}$, Hailing Wang $^{b}$, and Abir Al-Tabbaa ${ }^{a}$ \\ ${ }^{\mathrm{a}}$ Department of Engineering, University of Cambridge, Trumpington Street, \\ Cambridge, CB2 1PZ, UK (E-mail: fw281@cam.ac.uk; aa22@cam.ac.uk) \\ ${ }^{\mathrm{b} C o l l e g e}$ of Environment, Nanjing Tech University, Nanjing 210009, China. (E-mail: \\ wanghailing@njtech.edu.cn) \\ * Corresponding author
}

\section{Highlights:}

- The physical and chemical performances of most mixes were improved with time.

- Modified clays are efficient in immoblising Ni.

- A small amount of organo clay is able to improve the strength of samples.

- $\mathrm{M}(\mathrm{MgO})$ and $\mathrm{MG}(\mathrm{MgO}+\mathrm{GGBS})$ are efficient in immoblising heavy metals.

- $\mathrm{MgO}$ based blends have showing outstanding effect on treating organic pollutants. 


\title{
Time-dependent performance of soil mix technology stabilised/ solidified contaminated site soils
}

\author{
Fei Wang ${ }^{a}{ }^{*}$, Hailing Wang $^{b}$, and Abir Al-Tabbaa ${ }^{a}$ \\ ${ }^{\mathrm{a}}$ Department of Engineering, University of Cambridge, Trumpington Street, \\ Cambridge, CB2 1PZ, UK (E-mail: fw281@cam.ac.uk; aa22@cam.ac.uk) \\ ${ }^{\mathrm{b}}$ College of Environment, Nanjing Tech University, Nanjing 210009, China. (E-mail: \\ wanghailing@njtech.edu.cn) \\ * Corresponding author
}

Novelty Statement: The objective of this paper is to investigate the time-related performances of different binders (especially modified clays) in a heavy metals and organic contaminated site at 28 days and 1.5-year after treatment. Testing the time-related performances of these novel binders and addictives are required to expand the boundaries of the soil mixing technology and are necessary in validating the effectiveness of this remediation process. 


\title{
Time-dependent performance of soil mix technology stabilised/ solidified contaminated site soils
}

\author{
Fei Wang ${ }^{a}{ }^{*}$, Hailing Wang $^{b}$, and Abir Al-Tabbaa ${ }^{a}$ \\ ${ }^{\mathrm{a}}$ Department of Engineering, University of Cambridge, Trumpington Street, \\ Cambridge, CB2 1PZ, UK (E-mail: fw281@cam.ac.uk; aa22@cam.ac.uk) \\ ${ }^{\mathrm{b}}$ College of Environment, Nanjing Tech University, Nanjing 210009, China. (E-mail: \\ wanghailing@njtech.edu.cn)
}

ABSTRACT: This paper presents the strength and leaching performance of stabilised/solidified organic and inorganic contaminated site soil as a function of time and the effectiveness of modified clays applied in this project. Field trials of deep soil mixing application of stabilisation/solidification $(\mathrm{S} / \mathrm{S})$ were performed at a site in Castleford in 2011. A number of binders and addictives were applied in this project including Portland cement (PC), ground granulated blastfurnace slag (GGBS), pulverised fuel ash (PFA), MgO and modified clays. Field trial samples were subjected to unconfined compressive strength (UCS), BS CN 12457 batch leaching test and the extraction of total organics at 28 days and 1.5 years after treatment. The results of UCS test show that the average strength values of mixes increased from $0-3250 \mathrm{kPa}$ at 28 days to $250-4250 \mathrm{kPa}$ at 1.5 years curing time. The BS EN 12457 leachate concentrations of all metals were well below their drinking water standard, except $\mathrm{Ni}$ in some mixes exceed its drinking water standard at $0.02 \mathrm{mg} / \mathrm{l}$, suggesting that due to 
varied nature of binders, not all of them have the same efficiency in treating contaminated soil. The average leachate concentrations of total organics were in the range of $20-160 \mathrm{mg} / \mathrm{l}$ at 28 days after treatment and reduced to $18-140 \mathrm{mg} / \mathrm{l}$ at 1.5 years. In addition, organo clay (OC)/inorgano-organo clay (IOC) slurries used in this field trial were found to have a negative effect on the strength development, but were very effective in immobilising heavy metals. The study also illustrates that the surfactants used to modify bentonite in this field trail were not suitable for the major organic pollutants exist in the site soil in this project.

Keywords: Field trials; Modified clay; Novel binders; Soil stabilisation 


\title{
Time-dependent performance of soil mix technology stabilised/
} solidified contaminated site soils

\author{
Fei Wang $^{a}{ }^{*}$, Hailing Wang $^{b}$, and Abir Al-Tabbaa ${ }^{a}$ \\ ${ }^{a}$ Department of Engineering, University of Cambridge, Trumpington Street, Cambridge, CB2 \\ 1PZ, UK (E-mail: fw281@ cam.ac.uk; aa22@cam.ac.uk) \\ ${ }^{\mathrm{b}}$ College of Environment, Nanjing Tech University, Nanjing 210009, China. (E-mail: \\ wanghailing@njtech.edu.cn) \\ *Corresponding author. Tel.: +44 7909488269 \\ E-mail address: fw281@ cam.ac.uk (F. Wang)
}

A Paper Submitted for possible Publication as Research Papers to Journal of Hazardous Materials. 
ABSTRACT: This paper presents the strength and leaching performance of stabilised/solidified organic and inorganic contaminated site soil as a function of time and the effectiveness of modified clays applied in this project. Field trials of deep soil mixing application of stabilisation/solidification (S/S) were performed at a site in Castleford in 2011. A number of binders and addictives were applied in this project including Portland cement (PC), ground granulated blastfurnace slag (GGBS), pulverised fuel ash (PFA), $\mathrm{MgO}$ and modified clays. Field trial samples were subjected to unconfined compressive strength (UCS), BS CN 12457 batch leaching test and the extraction of total organics at 28 days and 1.5 years after treatment. The results of UCS test show that the average strength values of mixes increased from $0-3250 \mathrm{kPa}$ at 28 days to $250-4250 \mathrm{kPa}$ at 1.5 years curing time. The BS EN 12457 leachate concentrations of all metals were well below their drinking water standard, except $\mathrm{Ni}$ in some mixes exceed its drinking water standard at $0.02 \mathrm{mg} / \mathrm{l}$, suggesting that due to varied nature of binders, not all of them have the same efficiency in treating contaminated soil. The average leachate concentrations of total organics were in the range of $20-160 \mathrm{mg} / \mathrm{l}$ at 28 days after treatment and reduced to $18-140 \mathrm{mg} / \mathrm{l}$ at 1.5 years. In addition, organo clay (OC)/inorgano-organo clay (IOC) slurries used in this field trial were found to have a negative effect on the strength development, but were very effective in immobilising heavy metals. The study also illustrates that the surfactants used to modify bentonite in this field trail were not suitable for the major organic pollutants exist in the site soil in this project.

Keywords: Field trials; Modified clay; Novel binders; Soil stabilisation 


\section{INTRODUCTION}

Effectively treating organic and inorganic contaminated soil has been found to be a big challenge due to their nature and transport mechanisms in a soil environment [1]. Compared with existing treatment options, such as soil washing, biological methods, and disposal to landfill [2], soil mixing technology is a cost-effective, versatile, and low risk method for the implementation of a range of in-situ remediation treatments $[3,4]$. Stabilisation/solidification (S/S) as an application of soil mix technology has specific advantages relating to cost and environmentally friendliness [5]. The most popular materials in S/S are conventional binders such as Portland cement (PC) and lime [6], and some industrial by-products such as pulverised fuel ash (PFA) and ground granulated blastfurnace slag (GGBS) [7]. Recently, attention has been put on novel binders such as $\mathrm{MgO}$, and modified clays such as organo clay (OC), Inorgano-organo clay (IOC) [7, 8, 9]. OC is reported as being able to adsorb more organic pollutants compared to raw clays $[8,10]$. The modifications of bentonite to produce OC include oxide pillaring which modifies the layered crystalline inorganic compound to produce a material with micro and meso porosity, and organic surfactant modification through cation exchange with alkylammonium ions. The combination of these two methods forms IOC minerals, which can treat inorganics and organics simultaneously [11, 12]. However, studies of these binders, modified bentonites, have been mainly restricted to laboratory investigations [13]. Testing the performance of these novel binders and addictives is required to expand the boundaries of the soil mixing technology. In addition, whether a treatment technique is successful or not depends on its performance during its end-use expected lifetime [13]. Wang et al. [4, 25] studied the leaching performance of S/S treated samples at $0.2,2.4$, 5and 17 years, and found that lower concentration of heavy metals leached at 17 years after treatment than this at 5 years, and found that the hydration process of treated samples did not completed at 5 years but fully completed at 17 years. Roy and 


\section{SITE, MATERIAL AND METHODS}

Project SMiRT (Soil Mix Remediation Technology), was the largest contaminated land remediation project funded by the Technology Strategy Board. It involved collaboration with 16 industrial partners, over a four-year period which started in October 2007 and finished in September 2011 [3]. Soil treatment by S/S took place at a site in Castleford, Yorkshire in May 2011, as shown in Fig. 1. A triple auger system was applied which mixed contaminated soil with a range of binder blends consisting of PC, PFA, GGBS, MgO, Zeolite, OC and IOCs.

The geology at the site consists of top soil $(0.1-0.35 \mathrm{~m})$, made ground $(0.35-4.5 \mathrm{~m})$ (consisting of black sand and/or silt containing fragments of plastic, concrete and wood), silts and clays (4-6m) and sand and gravel (6-8m). Natural drift deposits were found in the silts and clays zone as well as the sand and gravel zone. The groundwater level varies between 3.2 and $3.9 \mathrm{~m}$ below ground level [14]. The water content of the soil is $\sim 25 \%$, the liquid limit is $\sim 30 \%$ and the plastic limit is $\sim 24 \%$. Due to historic disposal of waste materials, significant 
contamination was anticipated. Soil and groundwater samples were forwarded to Alcontrol Geochem in Chester (a URS approved laboratory) for chemical analysis at regular intervals during the fieldwork period [14]. Contaminants and their concentrations in the soil are listed in Table 1.

Although a total of 24 soil-grout compositions were applied at the site, only 14 of these mixes were selected for a detailed study in this paper. The layout of the 24 installations can be found in Fig. 1. PC (P), PFA (F), GGBS (G), MgO (M), OC and IOCs were materials used in the mixes, where each mixes were named after these materials' abbreviations. The 14 mixes were divided into 4 groups based on binder compositions for purpose of comparison, as shown in Table 2. The materials (excluding IOCs) used in this project were bought from material supply companies. The PC used in this project is CEM I. Granular OC used in the study was obtained from Amcol Minerals Europe Ltd (with di(hydrogenated tallow) dimethyl ammonium chloride and di(hydrogenated tallow) methyl ammonium chloride surfactants on sodium bentonite clay) and IOCs were prepared in the laboratory with their compositions detailed in Table 3. The binder ratios used in this project were based on a preliminary laboratory study. In Table 2, PG, PF, PFM and P in group 1 are PC based, the slurry content of which is $15 \%$; P-OC, P-2IOC1, P-IOC1, P-IOC3 in group 2 are $15 \%$ PC with different types of modified clays; PG-IOC3, PF-IOC3, PFM-IOC3, MG-IOC3 in group 3 are IOC3 based mixes, with $15 \%$ binders $+7.5 \%$ extra IOC3 slurry; $\mathrm{M}, \mathrm{MG}$ in group 4 are $\mathrm{MgO}$ based binders.

Sampling took place at 28 days after treatment, $1 \mathrm{~m}$ length cores were collected in sealed plastic tubes to $4 \mathrm{~m}$ depth. The diameter of the cores decreased with depth from $0-1 \mathrm{~m}$ : $90 \mathrm{~mm}$, 1-2m: 80mm, 2-3m: 70mm and 3-4m: 55mm. After testing at 28 days, samples were cured in their original sealed plastic tubes in a temperature controlled laboratory at $\sim 20^{\circ} \mathrm{C}$. The relative humidity of the lab is $\sim 50 \%$. 
A saw cutter was used to trim cores into sections each with a length equal to twice the diameter of the core [15-17]. The ends of the sections were made flat to within $\pm 0.05 \mathrm{~mm}$ (see Fig. 2). The samples were tested at 28 days and again at 1.5 years. A core length and trimmed section are illustrated in Fig. 2. The samples were subject to UCS testing in triplicate based on ASTM D4219-08 test method using a Uniframe 70-T0108/E loading frame. The crushed samples were then screened before subjected to batch leaching following BS 12457-2 [18]. $50 \mathrm{~g}$ of crushed core sample with particle sizes between 1 and $4 \mathrm{~mm}$ was added to 500 $\mathrm{ml}$ of carbonated deionised water $(\mathrm{pH}=5.4)$ to achieve a liquid to solid ratio $(\mathrm{L} / \mathrm{S})$ of 10:1. After 24 hours of agitation, the leachate solutions were filtered through a $0.45 \mu \mathrm{m}$ filter and tested for $\mathrm{pH}$ by a $\mathrm{pH}$ meter (EUTECH $\mathrm{pH} 510)$ and the concentration of the heavy metals was analysed using a Perkin Elmer 7000 inductively coupled plasma optical emission spectroscopy (ICP-OES).

The remaining liquid from the batch leaching test was transferred into a $1000 \mathrm{ml}$ plugcontained conical flask for organic extraction. $5 \mathrm{ml}$ of $12 \mathrm{M}$ hydrochloric acid was added to speed the extraction reaction and to act as a $\mathrm{pH}$ buffer. The extraction was conducted by adding $30 \mathrm{ml}$ dichloromethane (DCM) into the flask and shaking for 2 mins. After repeating this extraction process three times, the DCM with the extracted organics was poured into a container, and evaporated in a fume cupboard. After 48 hours, the mass of the residual organic mass was recorded [11]. All experiments were carried out at least in duplicate, in order to reduce the random error.

\section{RESULTS AND DISCUSSION}

\subsection{UCS}

Fig. 3 shows the average UCS values of triplicate samples for each mix at 28 days and 1.5 years. The deviation of UCS values for different binder mixes was in the range of 10-149 kPa. 
As can be seen from Fig. 3, the strength of PF-IOC3, MG-IOC3, M and PFM-IOC3 were too 
hydration process; 2) Bayat et al. [21] and Teerawattanasuk and Voottipruex [22] reported that the shear and yield strength increased when the content of bentonite increased, which can act as plastic fines; 3) the IOCs slurries increased the water content, which decreased the strength development [23]. When comparing P-2IOC1 with P-IOC1, it was found that doubling the IOC1 content reduced the strength to half at 28 days. It also was found that P2IOC1's strength increasement with time is significant.

At 28 days, most of mixes in group 3 were too weak to be tested. At 1.5 years the strength of all mixes in group 3 increased due to the continued hydration process. It was found that extra IOC3 added in this group resulted in decreased strength development, as can be seen from PG-IOC3, PF-IOC3, PFM-IOC3 in group 3 and PG, PF, PFM in group 1, and from MGIOC3 and MG at 28 days and at 1.5 years in Fig. 3. This is due to the adverse effect of higher water to binder ratio [23] as discussed above.

In group 4, the strength value of MG at 28 days at $\sim 3250 \mathrm{kPa}$ when other mixes in this group were too weak to be tested. The strength of MG continued to increase to $\sim 4200 \mathrm{kPa}$ at 1.5 years. MG was able to produce the highest UCS values among all mixes at both time points in this study. This is because $\mathrm{MgO}$ can activate GGBS and produce hydration products such as $\mathrm{C}-\mathrm{S}-\mathrm{H}$, magnesium silicate hydrates $(\mathrm{M}-\mathrm{S}-\mathrm{H})$ and hydrotalcite $\left(\mathrm{Mg}_{6} \mathrm{Al}_{2} \mathrm{CO}_{3}(\mathrm{OH})_{16} \bullet 4 \mathrm{H}_{2} \mathrm{O}\right)$ like phases (Ht), which contribute to strength development [24]. In addition, the 90\% GGBS used in MG can reduce the carbon footprint significantly. On the contrary, $\mathrm{M}$ in this group produced low strength as the hydration product of $\mathrm{MgO}\left(\mathrm{Mg}(\mathrm{OH})_{2}\right)$ is very weak.

\subsection{Leachate $\mathrm{pH}$ and leachability of the heavy metals}

Table 4 details the average leachate $\mathrm{pH}$ values and average leachate concentrations of $\mathrm{Cu}, \mathrm{Ni}$, $\mathrm{Pb}$ and $\mathrm{Zn}$ in 4 groups at 28 days and 1.5 years, with a maximum variation of $\pm 0.097 \mathrm{mg} / \mathrm{l}$. A decrease of $\mathrm{pH}$ values with time can be found among mixes in all groups. The $\mathrm{pH}$ at 28 days 
was in the range of 11.1-13.1, the values of which reduced to 8-12.2 at 1.5 years, due to carbonation or reactions with natural leachants $[4,25,26]$. This agrees well with previous $\mathrm{S} / \mathrm{S}$ $\mathrm{pH}$ values as a function of time reported by Wang et al. [4], who found that $\mathrm{pH}$ values of S/S treated site samples decreased from $\sim 10.5$ at 0.2 years to $\sim 7.6$ at 2.4 years and $\sim 7$ at 5 years and levelled off in the next 12 years.

From Table 4, it can be seen that the leachate concentrations of $\mathrm{Cu}, \mathrm{Pb}$ and $\mathrm{Zn}$ in all mixes were below the drinking water standard while the leachate concentrations of $\mathrm{Ni}$ in some mixes exceeded its drinking water standard $(0.02 \mathrm{mg} / \mathrm{l})$. Since cores were sampled after 28 days' in-site treatment and cured in the lab afterwards, the tested concentrations of heavy metals were supposed to be higher than the actual field samples. This is because these samples did not suffer from the rain wash. For most mixes, it was found that the leachate concentrations of heavy metals declined as a function of time. Specifically, group 1 showed limited efficiency in treating $\mathrm{Ni}$, with the leachate concentration of $\mathrm{Ni}$ in most mixes greater than its drinking water standard. This can be related to the higher leachate $\mathrm{pH}$ (at $\sim 11-12$ ) given by the hydration products of PC. The leachate concentrations of Ni reported by Wang et al. [4], were mainly above its solubility when $\mathrm{pH}>11$. Group 2 performed slightly better than groups 1 in terms of $\mathrm{Ni}$ immobilisation, with the leachate concentration of $\mathrm{Ni}$ in some of these mixes slightly higher than its drinking water standard, indicating the advantage of adding OC/IOCs.

In the presence of IOC 3 and $\mathrm{MgO}$, groups 3 and 4 performed better than the other 2 groups in immobilising Ni. This is because the non-ionic surfactant PPG in IOC3 increases the interlayer basal spacing of bentonite, which is sufficient for the removal of metal ions [27]. The findings also agree with studies by De Leon et al. [28] and Guerra et al. [29] that pillared bentonites have improved efficiency for metal removal. Comparing group 3 with group 2, it 
is obvious that IOC3 performed better than other modified clays for the immobilisation of heavy metals.

In group 4, the equilibrium $\mathrm{pH}$ of $\mathrm{Mg}(\mathrm{OH})_{2}$ is $\sim 10.5$, the value producing the lowest solubility of $\mathrm{Ni}(\mathrm{OH})_{2}$, hence $\mathrm{Ni}$ can be effectively immobilised [4]. Additionally, $\mathrm{Mg}(\mathrm{OH})_{2}$ has a layered structure which can adsorb heavy metals onto the surface of $\operatorname{Mg}(\mathrm{OH})_{2}$ or encapsulate heavy metals in its structure [19]. Furthermore, $\mathrm{MG}$ (with 10\% $\mathrm{MgO}$ ) proved to have much better buffering capacity than the PC based group. The leachate $\mathrm{pH}$ values, given by the high content of hydrotalcite-like phases in the hydration products of MG, were near the minimal solubility of most heavy metals [19].

\subsection{The leachability of total organics}

As can be seen from Fig. 4, the leachate concentrations of total organics in most mixes decreased in various degrees as a function of time. The deviation of concentrations of leached total organics was 1.9-72 mg/l. Group 2 leached the highest concentrations of total organics, followed by group 3 and group 1. Group 4, which leached the lowest concentrations of total organics, was observed as the best group in stabilising organic compounds.

In group 1, except PFM, the leachate concentrations of total organics in all mixes declined with time. This was due to further hydration taking place during the time intervals. PFM leached more total organics at 1.5 years, due to mixing conditions playing a major role in not only the strength development as mentioned above but also the leachability of total organics, while the hydration between a small amount of PC and PFA was not as severe as the mixing condition. Among the four PC based mixes, PF leached less organics: $<60 \mathrm{mg} / \mathrm{l}$ at 28 days and $<20 \mathrm{mg} / \mathrm{l}$ at 1.5 years, related to the high adsorption ability of PFA which has been previously studied a lot [30]. 
In group 2, high amounts of total organics were leached from samples at both time points suggesting that the hydration process of PC was inhibited by the extra water in IOCs slurry. When comparing the leached concentrations of total organics at 28 days and 1.5 years, a slight increase was found in the average concentrations of leached total organics of P-OC and P-2IOC1, while a slight decrease took place in P-IOC1 and P-IOC3. When considering the deviation of triplicate samples, no obvious trend can be found in group 1. The same situation was found in group 3, as can be expected by a high level of heterogeneity in the site soil.

After comparison among $\mathrm{P}$ and all the mixes in group 2, it is clear that mixing OC/IOCs with PC together is not very effective in immobilising organics. Although the intercalation of OC/IOCs was extended to some level, the layer structure factor was pointed out by Jiang and Zeng [10] as not significant to influence the organic pollutants adsorption but the surfactant modifiers. This deduced that the surfactants used to modify bentonite in this study are not suitable for the major organic pollutants in the site soil. This was proved by OuelletPlamondon et al. [27], who claimed that although PPG used in IOC3 can increase swelling of montmorillonite at lower concentration, the intercalation remained in the crystalline region, hence only small hydrocarbons can be removed by PPG modified bentonite.

When comparing PG, PF, PFM, MG with mixes in group 3 in sequence, IOC3 mixed with different binders showed adverse impact on immobilising organic compounds, suggesting that IOC3 is not effective in treating big molecular organics. Further studies of suitable surfactants for treating voluminous organic contaminants are needed.

In group 4, the average leachate concentrations of total organics in all mixes at 28 days (at $\sim 80 \mathrm{mg} / \mathrm{l}$ ) were $\sim 3$ times higher than these at 1.5 years (at $\sim 25 \mathrm{mg} / \mathrm{l}$ ), with the lowest deviation value $(<10 \mathrm{mg} / \mathrm{l})$, which indicates that the remediation effectiveness of group 4 in treating organic pollutants is more evident. The three most intense interplanar spacings (D) of brucite are $0.2365 \mathrm{~nm}, 0.477 \mathrm{~nm}$ and $0.1794 \mathrm{~nm}$ [31], and it was reported by Jordan and 
- A small amount of Organo clay is able to improve the strength of samples.

- Modified clays, especially Inorgano-organo clay 3, are efficient in immoblising Ni, but not very effective in stabilising big molecular organics and strength development. Further studies of modified clays which are suitable for treating large organic contaminants are needed.

- $\mathrm{M}(\mathrm{MgO})$ and $\mathrm{MG}(\mathrm{MgO}+\mathrm{GGBS})$ are efficient in immoblising $\mathrm{Ni}$ and have showing outstanding effect on treating organic pollutants.

- MG (MgO+GGBS, used 90\% by-product) had better physical and chemical performances compared to other mixes at 28 days and 1.5 years.

- PFA is effective in decreasing the leachability of organics but it increases the leachability of heavy metals.

\section{Acknowledgements}

This paper was written to support the SMiRT (soil mix remediation technology) project, the funding for which was supplied by the UK Technology Strategy Board with 16 industrial partners (Project TP/5/CON/6/I/H0304E). The project website is at http://wwwg.eng.cam.ac.uk/smirt. The authors are grateful to Schlumberger Foundation for its financial help of the PhD studentship for the first author, and many thanks to the proofreading by Fei Jin and David O'Connor.

\section{References}

[1] N. Jovic-Jovicic, A. Milutinovic-Nikolic, M. Zunic, Z. Mojovic, P. Bankovic, B. Dojcinovic, A. Ivanovic-Sasic, D. Jovanovic, Organobentonites as multifunctional adsorbents of organic and inorganic water pollutants, J. Serb. Chem. Soc. 79 (2) (2014) 253-263. 
[2] P. Falciglia, F.G.A. Vagliasindi, Stabilisation/solidification of Pb polluted soils: influence of contamination level and soil: binder ratio on the properties of cement-fly ash treated soils, Chem. Eng. Trans. 32 (2013) 385-390.

[3] A. Al-Tabbaa, M. Liska, S. Jegandan and P. Barker, Overview of project SMiRT for integrated remediation and ground improvement, In: International Symposium on Soil Mixing and Admixture Stabilisation, May, Okinawa, Japan, 2009.

[4] F. Wang, A. Al-Tabbaa, Leachability of 17-year old stabilised/solidified contaminated site soils, Geotech. SP. 2014, pp. 1612-1624. ISSN 0895-0563.

[5] R.B. Kogbara, A. Al-Tabbaa, Y. Yi, J.A. Stegemann, Cement-fly ash stabilisation/solidification of contaminated soil: Performance properties and initiation of operating envelopes, Appl. Geochem. 33 (2013) 64-75.

[6] M.D. La Grega, P.L. Buckingham, J.C. Evans, Stabilization and Solidification, in: Hazardous waste management. New York: Mc Graw-Hill Inc., 1994, pp. 641-704.

[7] F. Wang, H. Wang, A. Al-Tabbaa, The performance of blended conventional and novel binders in the in-situ stabilisation/solidification of a contaminated site soil, J. Hazard. Mater. 285 (2015) 46-52.

[8] C. Ouellet-Plamondon, R.J. Lynch, A. Al-Tabbaa, Comparison between granular pillared, organo- and inorgano-organo-bentonites for hydrocarbon and metal ion adsorption, Appl. Clay. Sci. 67-68 (2012) 91-98.

[9] S.M. Lee, D. Tiwari, Organo and inorgano-organo-modified clays in the remediation of aqueous solutions: An overview, Appl. Clay Sci. 59-60 (2012) 84-102.

[10] J. Jiang, Z. Zeng, Comparison of modified montmorillonite adsorbents : Part II: The effects of the type of raw clays and modification conditions on the adsorption performance, Chemosphere 53(1) (2003) 53-62. 
[11] C.M. Ouellet-Plamondon, Characterisation and performance of innovative aluminosilicates for soil mix technology permeable reactive barriers, PHD Thesis, Cambridge University, UK, 2011.

[12] K.G. Bhattacharyya, S.S. Gupta, Adsorption of a few heavy metals on natural and modified kaolinite and montmorillonite: A review, Adv. Colloid. Interfac. 140(2) (2008) 114131.

[13] A. Al-Tabbaa, CW. Evans, Pilot in situ auger mixing treatment of a contaminated site: Part 3. Time-related performance, Proce. Instn. Civ. Engrs. Geotech. Engng. 143 (2000) 103114.

[14] URS, Site investigation report, 26640-060-787-rpt1/rc/dk, UK, 2002.

[15] S. Srivastava, R. Chaudhary, D. Khale, Influence of $\mathrm{pH}$, curing time and environmental stress on the immobilization of hazardous waste using activated fly ash, J. Hazard. Mater. 153 (3) (2008) 1103-1109.

[16] A. Al-Tabbaa, C.W. Evans, Pilot in situ auger mixing treatment of a contaminated site: Part 1. Treatability study, Proc. Instn. Civ. Engrs. Geotech. Engng. 131(1998) 52-59.

[17] ASTM. Standard Test Methods for Compressive Strength of Molded Soil-Cement Cylinders, American Society for Testing and Materials, Philadelphia, 2007, D1633 - 00 (2007), DOI: 10.1520/D1633-00R07.

[18] BS EN 12457-2, Characterisation of Waste-Leaching-Compliance test for leaching of granular waste materials and sludges, British Standard, UK, 2002.

[19] F. Jin, Characterisation and performance of reactive MgO-based cements with supplementary cementitious materials, PHD Thesis, Cambridge University, UK, 2014.

[20] R.B. Kogbara, A. Al-Tabbaa, Mechanical and leaching behaviour of slag-cement and lime-activated slag stabilised/solidified contaminated soil, Sci. Tital. Environ. 409 (2011) $2325-2335$ 
[21] M. Bayat, E. Bayat, H. Aminpour, A. Salarpour, Shear strength and pore-water pressure characteristics of sandy soil mixed with plastic fine, Arab. J. Geosci. 7 (2014) 1049-1057. DOI 10.1007/s12517-012-0753-9.

[22] C. Teerawattanasuk, P. Voottipruex, Influence of clay and silt proportions on cementtreated fine-grained soil, J. Mater. Civ. Eng. 26 (2014) 420-428.

[23] M. Nehdi, A.M. Soliman, Early-age properties of concrete: overview of fundamental concepts and state-of-the-art research, ICE Constr. Mater. 164 (2) (2011) 57-77.

[24] F. Jin, K. Gu, A. Abdollahzadeh, A. Al-Tabbaa, Effect of different reactive MgOs on the hydration of MgO-activated ground granulated blastfurnace slag paste, J. Mater. Civ. Eng. 2013; 10.1061/(ASCE)MT.1943-5533.0001009 (Dec. 21, 2013).

[25] F. Wang, H. Wang, A. Al-Tabbaa, Leachability and heavy metal speciation of 17-year old stabilised/solidified contaminated site soils, J. Hazard. Mater. 278 (2014) 144-151.

[26] R.B. Kogbara, A. Al-Tabbaa, Y. Yi, J.A. Stegemann, pH-dependent leaching behaviour and other performance properties of cement-treated mixed contaminated soil, J. Environ. Sci. 24 (9) (2012) 1630-1638.

[27] C.M. Ouellet-Plamondon, J. Stasiak, A. Al-Tabbaa, The effect of cationic, non-ionic and amphiphilic surfactants on the intercalation of bentonite, Colloid. Surface A. 444 (2014) 330337.

[28] A.T. De Leon, D.G. Nunes, J. Rubio, Adsorption of Cu ions onto a 1.10 phenanthrolinegrafted brazilian bentonite, Clay Clay Miner. 51(1) (2003) 58-64.

[29] D.L. Guerra, C. Airoldi, V.P. Lemos, R.S. Angélica, Adsorptive, thermodynamic and kinetic performances of $\mathrm{Al} / \mathrm{Ti}$ and $\mathrm{Al} / \mathrm{Zr}$-pillared clays from the Brazilian Amazon region for zinc cation removal, J. Hazard. Mater. 155(1-2) (2008) 230-242.

[30] S.A. Leonard, J.A. Stegemann, Stabilization/solidification of petroleum drill cuttings: Leaching studies, J. Hazard. Mater. 174 (2010) 484-491. 
[31] http://webmineral.com/MySQL/xray.php?ed1=2.365\&minmax=2\#.VCH6mZRdXrw.

[32] G. Jordan, W. Rammensee, Dissolution rates and activation energy for dissolution of brucite (001): A new method based on the microtopography of crystal surfaces, Geochim. Cosmochim. Ac. 60 (24) (1996) 5055-5062.

[33] G.S. Xeidakis, Stabilization of swelling clays by $\operatorname{Mg}(\mathrm{OH})_{2}$ : Changes in clay properties after addition of Mg-hydroxide, Eng. Geol. 44 (1996) 107-120.

[34] G.P. Gillman, Hydrotalcite: leaching-retarded fertilizers for sandy soils, in: Management of tropical sandy soils for sustainable agriculture, Khon Kaen, Thailand, 2005, pp. 107-111. [35] A. Al-Tabbaa, M. Liska, C. Ouellet-Plamondon, S. Jegandan, R. Shrestha, P. Barker, R. McGall, and C. Critchlow, Soil mix technology for integrated remediation and ground improvement: From laboratory work to field trials, 4 th Int. Conf. Grouting and Deep Mixing, February, New Orleans, 2012.

[36] Z. Abunada, A. Al-Tabbaa, Performance evaluation of inorgano-organo bentonite barrier materials in the remediation of chlorinated contaminated groundwater, 7th ICEG, November, Melbourne, 2014.

[37] A, Roy, F.K. Cartledge, Long-term behavior of a portland cement electroplating sludge waste form in presence of copper nitrate, J. Hazard. Mater. 52 (2-3) (1997) 265-286.

\section{List of Figure Captions}

Figure 1. Plan of field trials treatment.

Figure 2. Description of SMiRT site cores and a trimmed core at 1.5 years.

Figure 3. The average UCS values of mixes at 28 days and 1.5 years.

Figure 4. Leachability of total organics in the soil treated mixes. 
Table 1. Soil contaminant concentrations [35].

\begin{tabular}{cc} 
Metals or Organic contaminants & $\begin{array}{c}\text { Concentration range } \\
(\mathbf{m g} / \mathbf{k g})\end{array}$ \\
$\mathrm{Pb}$ & $95-175$ \\
$\mathrm{Zn}$ & $150-220$ \\
$\mathrm{As}$ & $130-140$ \\
$\mathrm{Cr}$ & $700-1150$ \\
$\mathrm{Cu}$ & $1075-1600$ \\
$\mathrm{Ni}$ & $1170-2200$ \\
VOCs: BTEX & $\leq 7$ \\
SVOCs: anilines, chloroanilines, nitrobenzenes, dinitrotoluene & $\leq 1400$ \\
$\mathrm{TPH}$ & $\leq 8000$ \\
\hline
\end{tabular}


Table 2. Description of the soil-grout mixes.

\begin{tabular}{|c|c|c|c|c|c|c|c|c|}
\hline Group & \multicolumn{3}{|c|}{ Binder } & $\begin{array}{c}\text { Organo } \\
\text { clay }\end{array}$ & $\begin{array}{c}\text { Binder } \\
\text { components } \\
\text { ratio }\end{array}$ & $\begin{array}{c}\text { Slurry } \\
\text { content } \\
\text { (wt })\end{array}$ & $\begin{array}{c}\text { Water } \\
\text { Cement } \\
\text { ratio }\end{array}$ \\
\hline $\begin{array}{c}\text { Group } \\
1\end{array}$ & PG & PC & GGBS & & & $1: 1$ & 15 & $1: 1$ \\
\cline { 2 - 10 } & PF & PC & PFA & & & $1: 2$ & 15 & $1: 1$ \\
\cline { 2 - 10 } & PFM & PC & PFA & MgO & & $1: 4: 5$ & 15 & $1: 1$ \\
\cline { 2 - 10 } \\
\cline { 2 - 10 }
\end{tabular}


Table 3. Composition of inorgano-organoclay (IOC) slurries [36].

\begin{tabular}{|l|c|c|c|}
\hline Slurry IOC per $\mathbf{1} \mathbf{~ m}^{\mathbf{3}}:$ \\
\hline & & Amount (kg) & Dilution \\
\hline IOC 1 & Bentonite KM & 75 & \\
\hline & Water & 900 & $1: 9$ \\
\hline & Chlorhydrol & 34 & $1: 2$ \\
\hline IOC 3 & MCB50 & 37.5 & \\
\hline & Bentonite KM & 75 & \\
\hline & Water & 900 & $1: 9$ \\
\hline & Chlorhydrol & 34 & $1: 2$ \\
\hline
\end{tabular}


Table 4. Leachate $\mathrm{pH}$ and leachability of heavy metals in the made ground.

\begin{tabular}{|c|c|c|c|c|c|c|c|c|c|c|c|}
\hline \multirow[t]{2}{*}{ Group } & \multirow[t]{2}{*}{ Mix } & \multicolumn{5}{|c|}{28 days $(\mathrm{mg} / \mathrm{l})$} & \multicolumn{5}{|c|}{1.5 years $(\mathrm{mg} / \mathrm{l})$} \\
\hline & & $\mathrm{pH}$ & $\mathrm{Ni}$ & $\mathrm{Cu}$ & $\mathrm{Zn}$ & $\mathrm{Pb}$ & $\mathrm{pH}$ & $\mathrm{Ni}$ & $\mathrm{Cu}$ & $\mathrm{Zn}$ & $\mathrm{Pb}$ \\
\hline \multirow[t]{4}{*}{ Group 1} & PG & 11.7 & 0.017 & 0.173 & 0.001 & 0.001 & 9.7 & 0.018 & 0.157 & 0.024 & 0.000 \\
\hline & PF & 11.9 & 0.111 & 0.389 & 0.000 & 0.003 & 8.0 & 0.050 & 0.059 & 0.002 & 0.000 \\
\hline & PFM & 12.0 & 0.098 & 0.071 & 0.003 & 0.004 & 8.0 & 0.000 & 0.000 & 0.007 & 0.000 \\
\hline & $\mathrm{P}$ & 12.5 & 0.051 & 0.140 & 0.001 & 0.004 & 11.4 & 0.042 & 0.225 & 0.019 & 0.000 \\
\hline \multirow[t]{4}{*}{ Group 2} & P-OC & 13.1 & 0.011 & 0.045 & 0.002 & 0.002 & 12.2 & 0.037 & 0.241 & 0.026 & 0.000 \\
\hline & P-2IOC1 & 12.5 & 0.121 & 0.411 & 0.001 & 0.008 & 11.8 & 0.084 & 0.153 & 0.025 & 0.001 \\
\hline & P-IOC1 & 12.3 & 0.041 & 0.141 & 0.001 & 0.004 & 11.6 & 0.040 & 0.260 & 0.002 & 0.001 \\
\hline & P-IOC3 & 12.5 & 0.030 & 0.101 & 0.001 & 0.005 & 11.8 & 0.026 & 0.116 & 0.033 & 0.001 \\
\hline \multirow[t]{4}{*}{ Group 3} & PG-IOC3 & 12.1 & 0.023 & 0.104 & 0.001 & 0.002 & 10.3 & 0.006 & 0.084 & 0.000 & 0.000 \\
\hline & PF-IOC3 & 11.7 & 0.037 & 0.195 & 0.001 & 0.001 & 10.5 & 0.012 & 0.142 & 0.000 & 0.000 \\
\hline & PFM-IOC3 & 12.1 & 0.012 & 0.043 & 0.001 & 0.001 & 10.7 & 0.001 & 0.038 & 0.003 & 0.000 \\
\hline & MG-IOC3 & 12.4 & 0.029 & 0.040 & 0.006 & 0.002 & 9.1 & 1.237 & 3.098 & 0.237 & 0.005 \\
\hline \multirow[t]{2}{*}{ Group 4} & $M$ & 11.1 & 0.004 & 0.020 & 0.001 & 0.022 & 10.1 & 0.000 & 0.015 & 0.000 & 0.000 \\
\hline & MG & 12.0 & 0.010 & 0.097 & 0.002 & 0.002 & 11.3 & 0.027 & 0.040 & 0.018 & 0.000 \\
\hline DWS & & & 0.020 & 2 & 5 & 0.025 & & 0.020 & 2 & 5 & 0.025 \\
\hline LOD & & & 0.009 & 0.004 & 0.006 & 0.006 & & 0.009 & 0.004 & 0.006 & 0.006 \\
\hline
\end{tabular}

LOD: limit of detection; DWS: drinking water standard (HMSO, 2009); standard deviation: 0.001-0.097. 

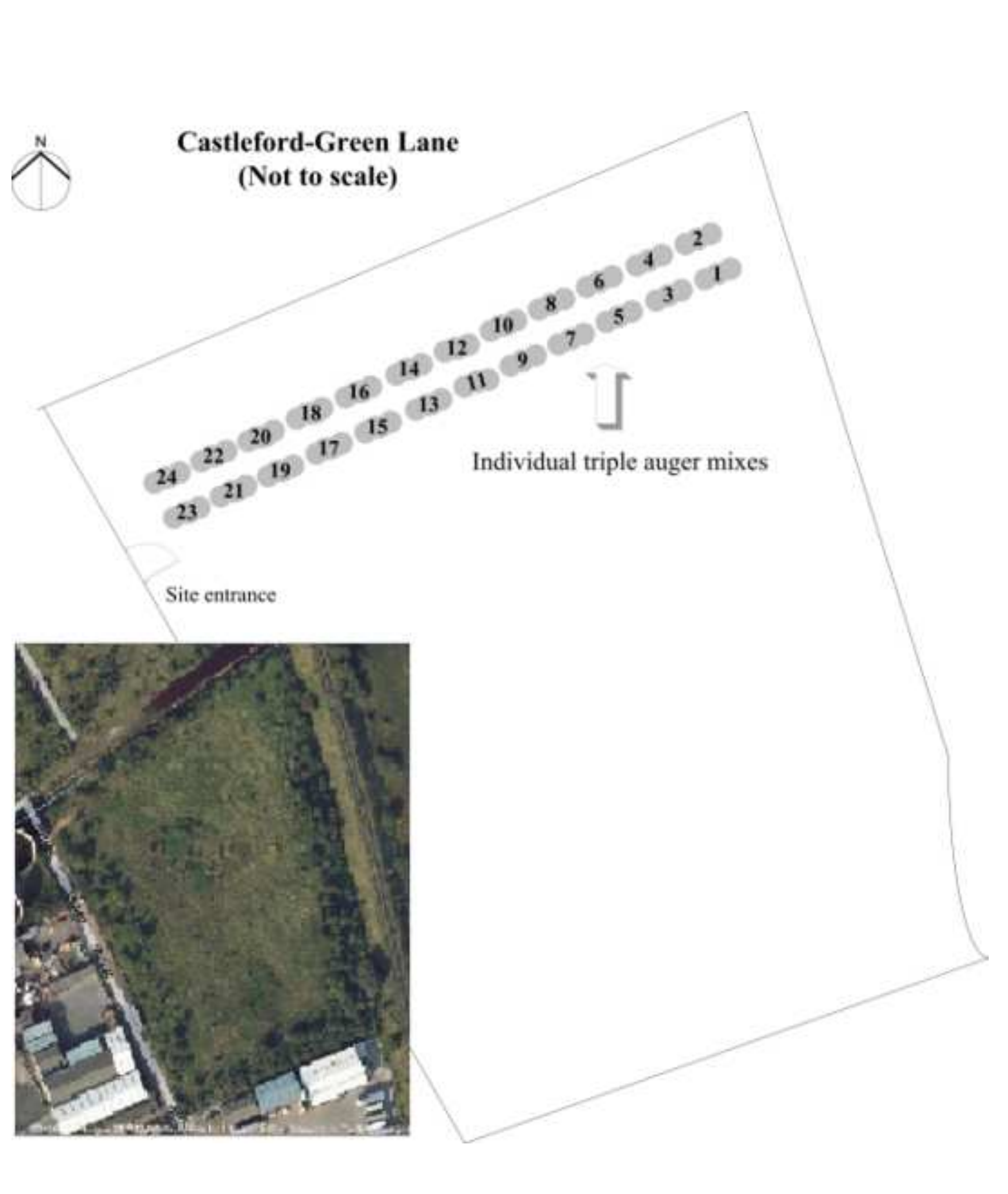


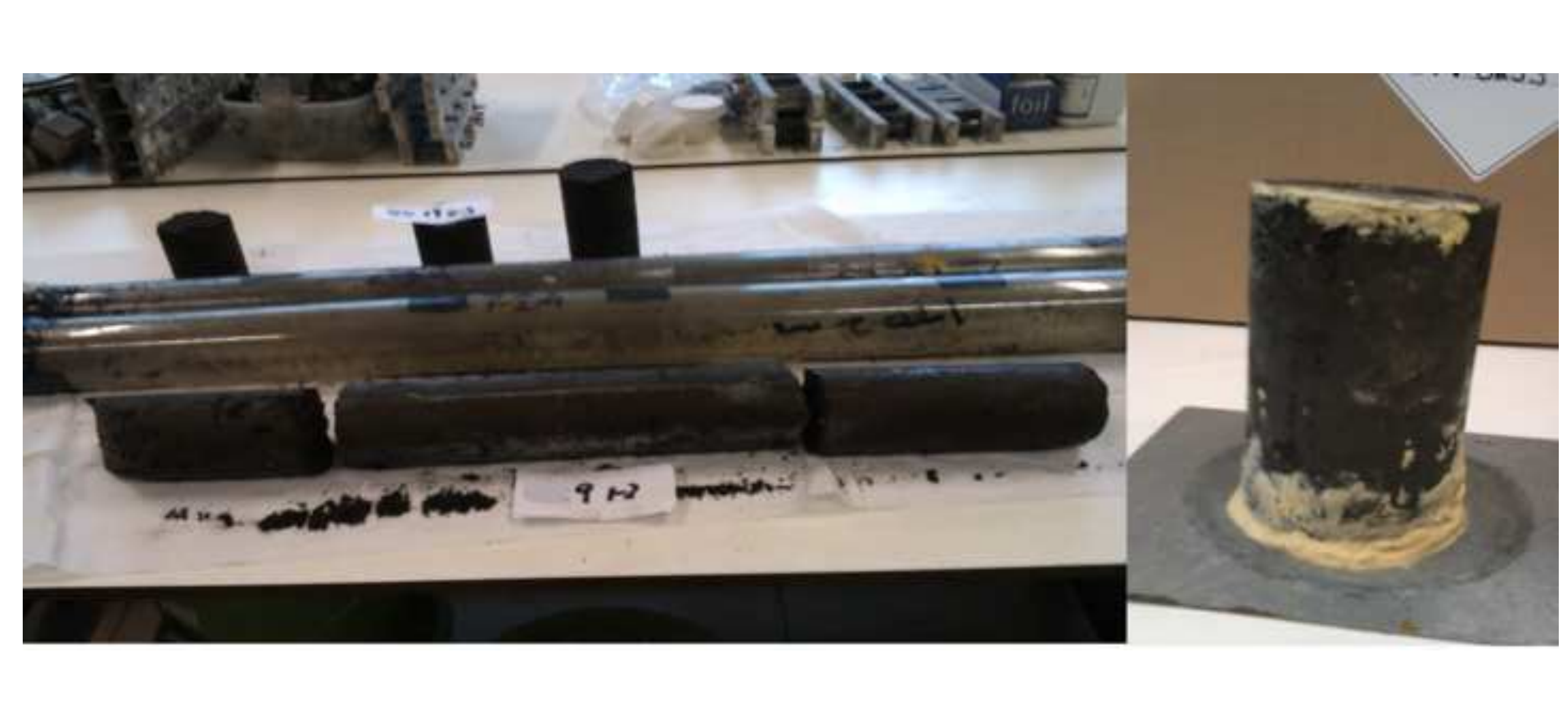

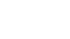 \\ .}
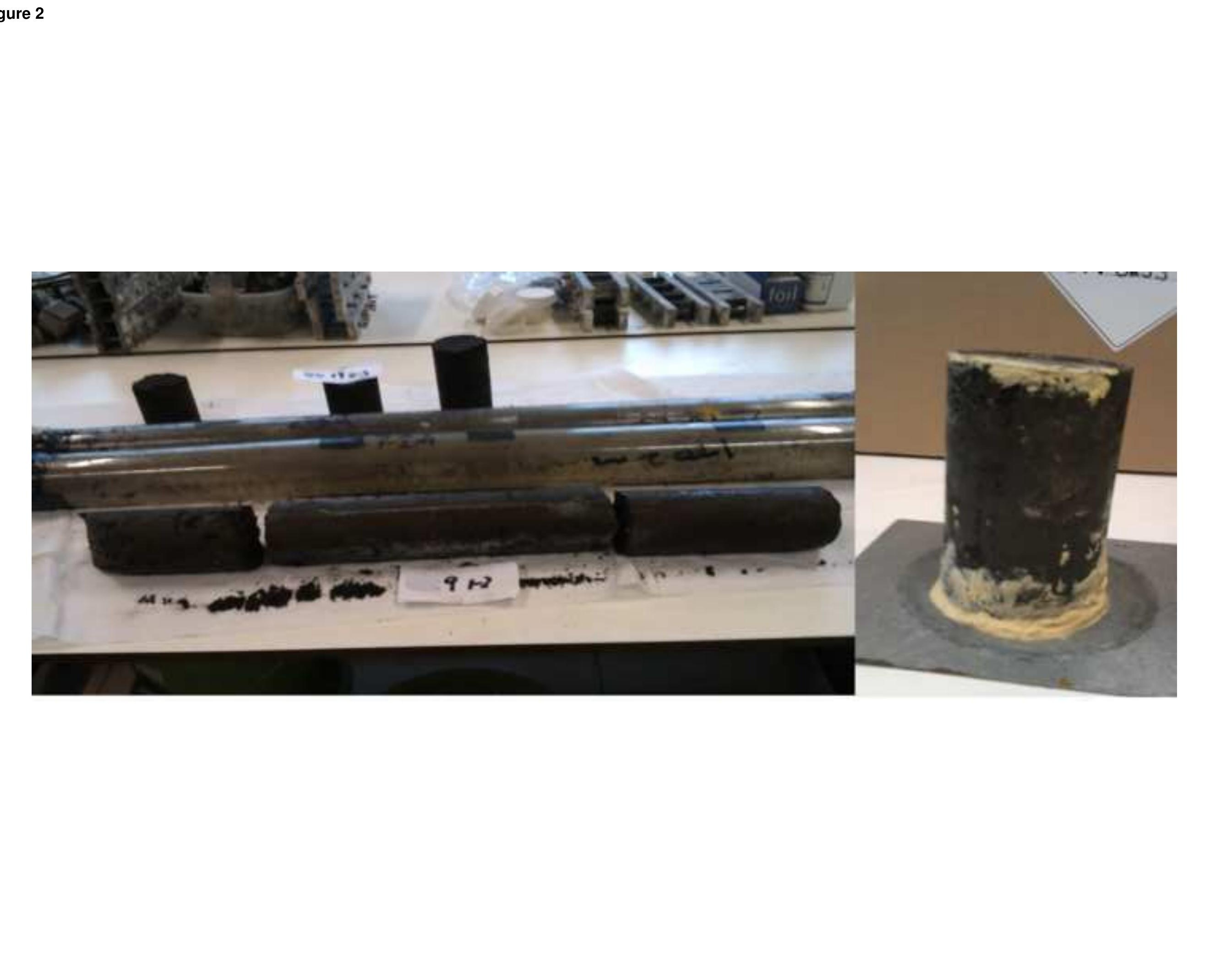

.
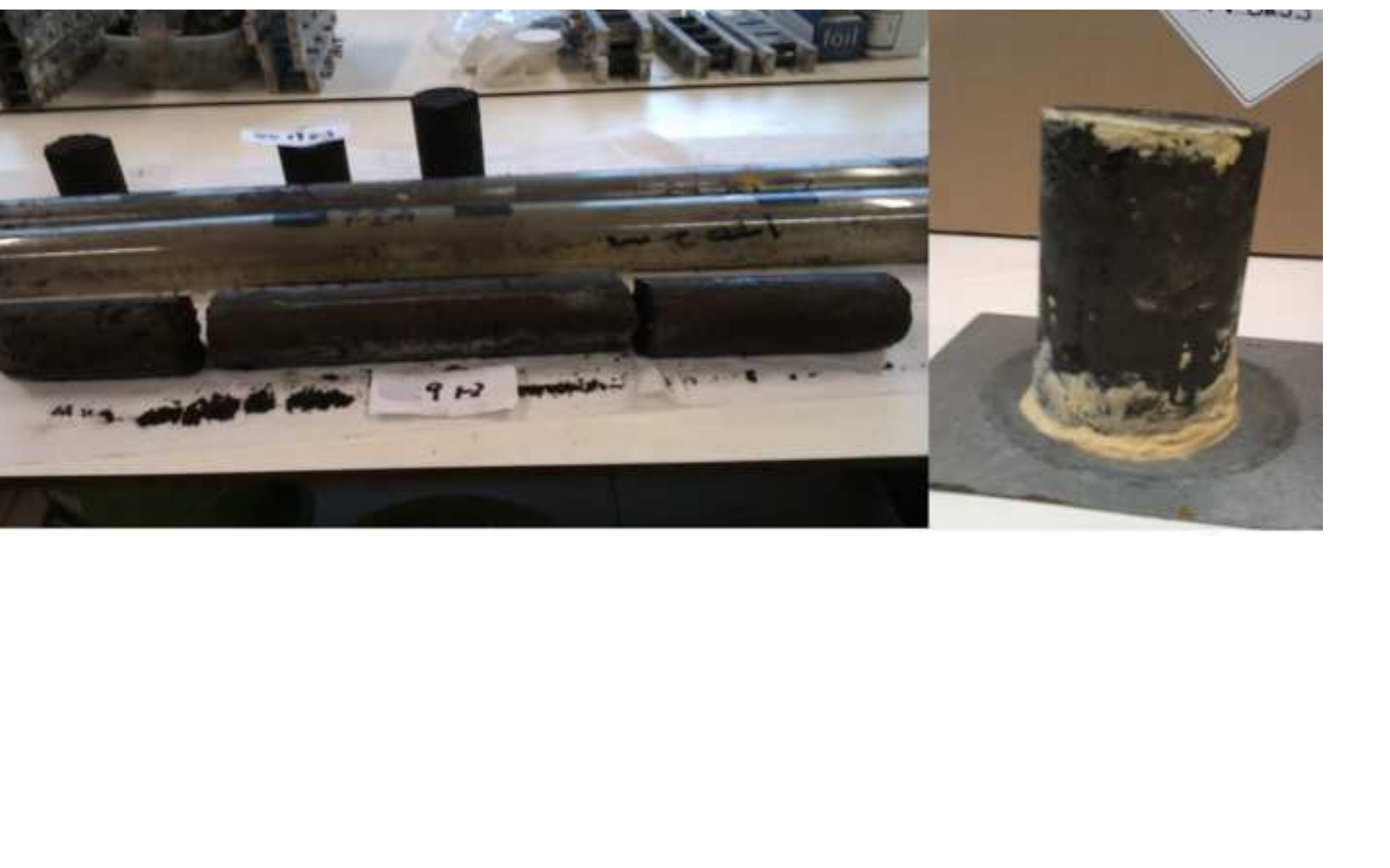


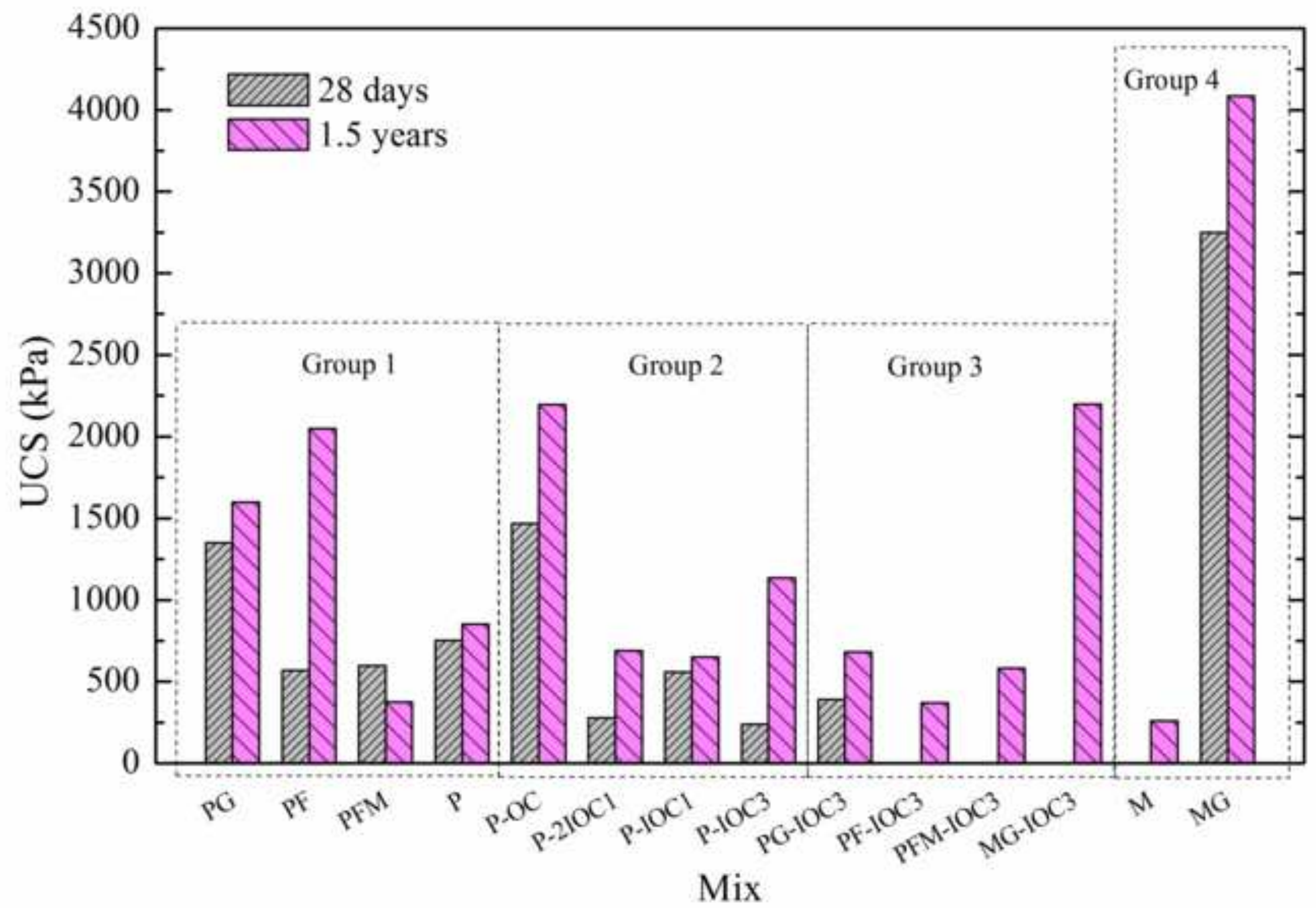




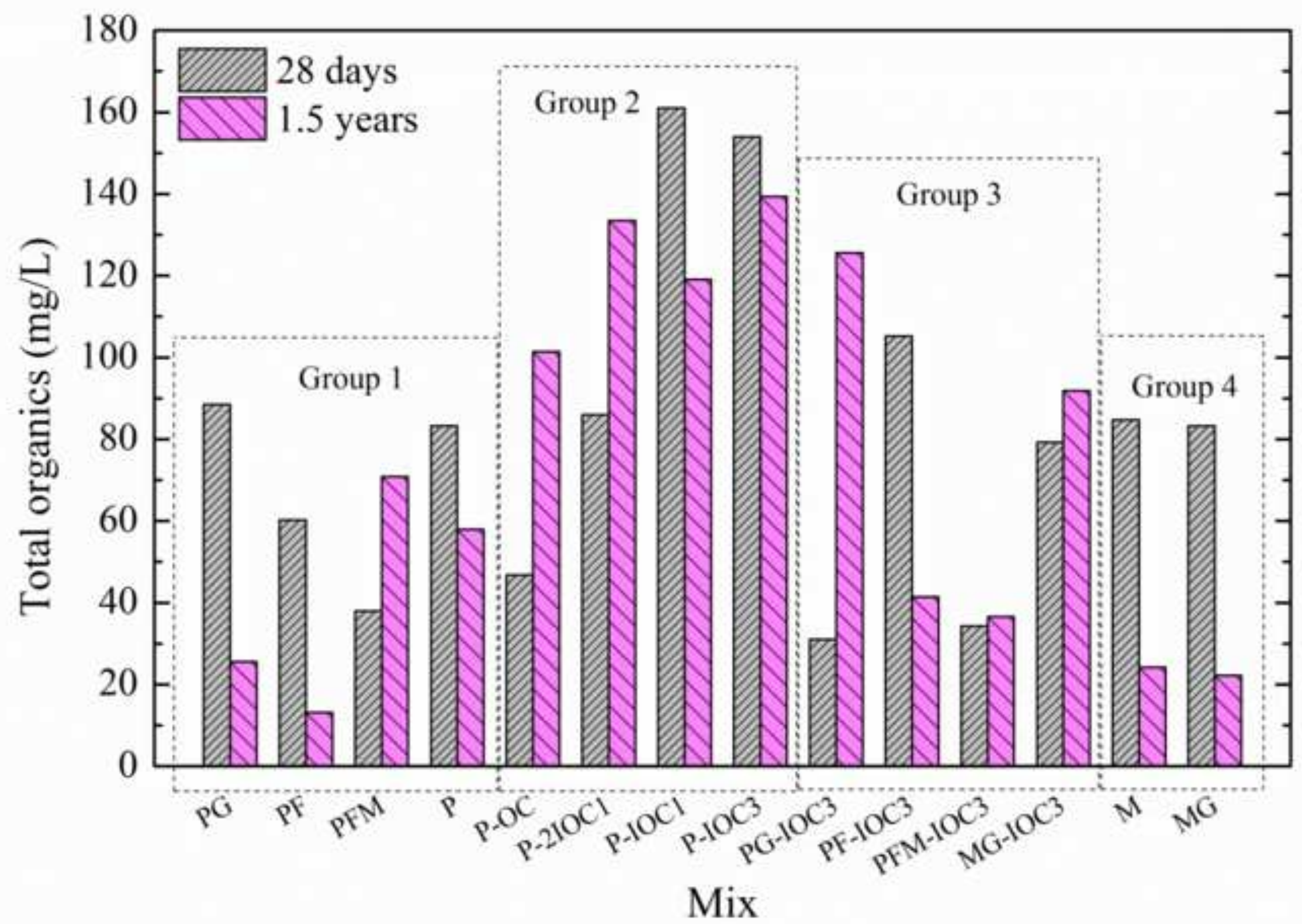

